\title{
Helium isotopes at the Rainbow hydrothermal site (Mid-Atlantic Ridge, $36^{\circ} 14^{\prime} \mathrm{N}$ )
}

\author{
Philippe Jean-Baptiste ${ }^{a}$, Elise Fourréa ${ }^{\text {, Jean-Luc Charlou }}{ }^{b}$ Christopher R. German $^{c}$ \\ and Joel Radford-Knoery ${ }^{b}$
}

\author{
aPSL/LSCE, UMR CEA-CNRS 1572, CE Saclay, 91191, Gif-sur-Yvette Cedex, France \\ ' IFREMER, DRO-GM, Centre de Brest, P.O. Box 70, 29280, Plouzané, France \\ 'Southampton Oceanography Centre, Empress Dock, Southampton S014 3ZH, UK \\ *: Corresponding author : Tel.: +33-169087714; Fax: +33-169087716 pib@lsce.saclay.cea.fr
}

\begin{abstract}
The $3 \mathrm{He} / 4 \mathrm{He}$ ratio and helium concentration have been measured in the vent fluids and the dispersing plume of the Rainbow hydrothermal site, on the Mid-Atlantic Ridge (MAR). The $3 \mathrm{He} / 4 \mathrm{He}$ ratio $(7.51 \mathrm{Ra})$ and $3 \mathrm{He}$ end-member concentration $(25 \mathrm{pmol} / \mathrm{kg})$ are in the range of observed values elsewhere on mid-ocean ridges, pointing to the relative homogeneity of the upper mantle with respect to helium isotope geochemistry. $3 \mathrm{He}$ is linearly correlated with methane and manganese throughout the plume, with $\mathrm{CH} 4 / 3 \mathrm{He}$ and $\mathrm{Mn} / 3 \mathrm{He}$ ratios identical to those measured in the hot fluids. The bulk residence time of the plume in the rift valley estimated from the plume $3 \mathrm{He}$ budget is not, vert, similar20 days. The $3 \mathrm{He}$ flux transported by the plume, calculated from current-meter data, is $12.3 \pm 3$ $\mathrm{nmol} / \mathrm{s}$, requiring a flux of $490 \mathrm{~kg} / \mathrm{s}$ of high-temperature fluid. The scaling of the heat flux emitted by the Rainbow site to that of $3 \mathrm{He}$, using the $3 \mathrm{He} /$ heat ratio measured in the hydrothermal fluids $(9.3 \pm 2 \times 10-18 \mathrm{~mol} / \mathrm{J})$, indicates a heat output of $1320 \mathrm{MW}$. With a regional spreading rate of not, vert, similar25 mm/year, we calculate that the annual $3 \mathrm{He}$ flux for this section of the MAR is of the order of $0.5 \pm 0.2 \mathrm{mmol}$ per kilometre of ridge per millimetre of newly formed crust. This figure compares well with the flux calculated for the neighbouring Lucky Strike segment. Although the uncertainties remain large, both fluxes are not, vert, similar $40-50 \%$ above the world average $(0.33 \mathrm{mmol} / \mathrm{km} / \mathrm{mm})$, thus supporting earlier suggestions that the intensity of the hydrothermal activity south of the Azores is higher than expected from the regional spreading rate.
\end{abstract}

Keywords: helium; hydrothermal vents; isotopes; heat flux; Mid-Atlantic Ridge 


\section{Introduction}

The Rainbow hydrothermal plume (Mid-Atlantic-Ridge, $36^{\circ} 14^{\prime} \mathrm{N}$ ) was first identified in 1994 from the detection of optical back-scatter anomalies [1]. In the year 1997, a detailed survey of the site was undertaken as part of the EU Amores project, including physical oceanography and geochemical study of the hydrothermal plume dispersal. Seafloor investigations where also carried out with the submersible Nautile, which led to the discovery and study of the active vents [2]. Here we report helium isotopes results for the high temperature fluids and the hydrothermal plume. In the following, the helium ${ }^{3} \mathrm{He} /{ }^{4} \mathrm{He}$ isotope ratio, $R$, is expressed either relative to the atmospheric ratio $\left(R_{a}=1.38 \times 10^{-6}\right)$ or using the delta notation, $\delta^{3} \mathrm{He}(\%)=\left(\mathrm{R} / \mathrm{R}_{\mathrm{a}}-1\right) \times 100$. With regards to hydrothermal processes, the helium isotopes represent a useful tracer in two different ways : first, owing to the clearly distinct ${ }^{3} \mathrm{He} /{ }^{4} \mathrm{He}$ signature of the different solid earth reservoirs, including the depleted upper mantle $\left({ }^{3} \mathrm{He} /{ }^{4} \mathrm{He}=7-9 \mathrm{R}_{\mathrm{a}}\right)$, the lower mantle $\left({ }^{3} \mathrm{He} /{ }^{4} \mathrm{He}>30 \mathrm{R}_{\mathrm{a}}\right)$ and the continental crust $\left({ }^{3} \mathrm{He} /{ }^{4} \mathrm{He}\right.$ $<0.1 \mathrm{R}_{\mathrm{a}}$ ), helium isotope ratio is a good indicator of the source of the hydrothermal fluids. Second, due to its high concentration in vent fluids compared to seawater and to its chemical inertness, ${ }^{3} \mathrm{He}$ provides a faithful tracer of fluid dilution and plume dispersion.

\section{Geological and hydrographic settings}

The Rainbow site lies at $36^{\circ} 13.8^{\prime} \mathrm{N}-33^{\circ} 54.12^{\prime} \mathrm{W}$ along the western flank of a topographic high (the Rainbow ridge) located at the western end of a non-transform discontinuity between the South AMAR and AMAR segments (fig.1). The hydrothermal site consists of a $100 \times 200 \mathrm{~m}$ active vent field, between $2270 \mathrm{~m}$ and $2330 \mathrm{~m}$ depth, displaying extensive stockwork mineralization. Ten major groups of active black smokers emit hot temperature $\left(\mathrm{T}=365^{\circ} \mathrm{C}\right)$ acidic fluids. Unlike the previously discovered Menez Gwen and Lucky Strike hydrothermal sites south of the Azores, which are located in a basaltic environment, the Rainbow site is nested in serpentinized ultramafic rocks. This specific 
geological environment strongly influences the chemistry [3] and gas content of the fluids, which show exceptionally high hydrogen concentration attributed to the serpentinization process [4].

Physical oceanography data, including CTD, LADCP and long-term current-meter moorings [5-6], as well as the spatial distribution of optical back-scatter anomalies, reveal that the hydrothermal plume is advected to the northeast along the rift valley of the AMAR segment as a single spatially and temporaly coherent structure, detectable over a distance of several tens of kilometers away from its source [6-7].

\section{Sample collection and analytical methods}

Water samples were taken in the rift valley on each side of the Rainbow ridge from a series of CTD-rosette vertical and "tow-yo" casts designed to obtain a 3-D picture of the hydrothermal plume. The water samples were stored in sealed copper tubes and returned to the laboratory for subsequent gas extraction and mass spectrometry measurement with a VG 3000 mass spectrometer using routine analysis procedures [8]. The accuracy in the $\delta^{3} \mathrm{He}(\%)$ excess is better than \pm 0.3 , and the relative standard deviation of the absolute ${ }^{4} \mathrm{He}$ concentration is $0.8 \%$.

Helium isotope analyses were also performed on high temperature vent samples collected in 750-ml gas-tight titanium syringes. These sampling devices, developed at IFREMER for the french submersibles Cyana and Nautile, have been used routinely since the early 80 's for hydrothermal gas studies. Leak tests carried out at various pressures in the high pressure facility at IFREMER have shown that these syringes, if properly maintained, are totally reliable to recover gassy samples such as those found in hot hydrothermal systems. The consistency of the $\mathrm{Mn} /{ }^{3} \mathrm{He}$ and $\mathrm{Mn} / \mathrm{CH}_{4}$ ratios recorded in the plume and in the hot fluids (see fig.4) is a further evidence that the gas phase was adequately sampled. On deck, the fluid samples were transferred immediately in a specially designed evacuated degassing tank 
ensuring $100 \%$ gas recovery. During the transfer procedure, the syringes were kept under water to avoid any contamination by atmospheric air. The degassing tank is a development of the prototype used in previous studies [9]. The main improvement consists in the addition of a membrane pump which ensures the complete transfer of the dissolved species from the degassing tank to a small stainless steel container through a drying column. The pressure in various parts of the equipment is monitored by miniature digital sensors. The measured pressure after the drying column makes it possible to determine the exact amount of dissolved gases [10-12]. In parallel to the stainless steel container, gas aliquots were also taken in small copper tubes tightly sealed with special clamps for helium isotopes analysis. In the laboratory, the copper tubes were directly connected to the inlet system of the mass spectrometer for isotopic analysis [8]. The uncertainty in the isotopic ratio is within $\pm 0.05 R_{a}$, with a relative error in the total helium concentration $<5 \%$.

\section{Results}

\subsection{Plume data}

The vertical structure of the plume (fig. 2) shows pronounced $\delta^{3} \mathrm{He}$ anomalies in a near constant depth range between 2000 and 2300 meters, with increasing values up to $37 \%$ close to the vent site. This value is high compared to the background value of the deep Atlantic waters, around 5\% at this latitude and depth [13-14]. The near-field plume exhibits two maxima at two different depths off-set by 40-50 meters (fig. 2), consistent with the nephelometry data [6]. This interval nearly corresponds to the depth interval spanned by the active vents on the Rainbow ridge so that this double plume is likely due to discrete contributions from the different vents. However, it has been observed in the TAG hydrothermal site [15] that a plume rise-height can vary by more than a hundred meters as a function of tidal cycling. Therefore, this double peak structure could also be due to a similar phenomenon. The stations southwest of the ridge show no $\delta^{3} \mathrm{He}$ anomaly (fig.3). This is in 
agreement with the structure of the deep currents recorded by long term moorings $(\sim 400$ days), which indicate a persistent northeastward advection of the plume [5]. The $\delta^{3} \mathrm{He}$ horizontal section at plume height (fig. 3) shows that the plume is detectable over a distance of about $30 \mathrm{~km}$.

Throughout the dispersing plume, helium-3 is linearly correlated with manganese and methane (fig. 4), with slopes of $(110 \pm 10) \times 10^{6}$ and $(131 \pm 16) \times 10^{6}$ for $\mathrm{Mn} /{ }^{3} \mathrm{He}$ and $\mathrm{CH}_{4} /{ }^{3} \mathrm{He}$ ratios respectively.

\subsection{Vent fluids data}

The fluids are characterized by a rather uniform chemical composition indicating a single deep supply for the various vents [3-4]. The ${ }^{3} \mathrm{He} /{ }^{4} \mathrm{He}$ ratio, $\mathrm{R}$, obtained from the slope of the ${ }^{3} \mathrm{He}-{ }^{4} \mathrm{He}$ diagram (Fig. 5a), is $(7.51 \pm 0.02) \mathrm{R}_{\mathrm{a}}$, which is within the $7-9 \mathrm{R}_{\mathrm{a}}$ range of MORB value. Helium concentrations (Table 1) are plotted in Fig. 5b against magnesium, used as an indicator of the dilution factor of the hydrothermal end-member with ambient seawater. The data define a helium $\left({ }^{4} \mathrm{He}\right)$ end-member of $2.41 \pm 0.5 \mu \mathrm{mol} / \mathrm{kg}$, corresponding to a ${ }^{3} \mathrm{He}$ concentration of $25 \pm 5 \mathrm{pmol} / \mathrm{kg}$.

End-member hydrothermal tracer ratios in the hot fluids are $(94 \pm 20) \times 10^{6}$ and $(108 \pm 37) \times 10^{6}$ for $\mathrm{Mn} /{ }^{3} \mathrm{He}$ and $\mathrm{CH}_{4} /{ }^{3} \mathrm{He}$ ratio respectively. The ${ }^{3} \mathrm{He} /$ heat ratio corresponding to the fluid output temperature of $365^{\circ} \mathrm{C}$ is $(9.3 \pm 2) \times 10^{-18} \mathrm{~mol} / \mathrm{J}$.

\section{Discussion}

One of the main achievement of the Amores project was to deliver a coherent integrated data set of the physical and geochemical variables relevant to the study of an active venting site and its plume dispersal. In addition to presenting new data for hydrothermal tracers in a rather unusual (ultramafic) environment that permits comparison with other sites, this combined vent site/plume approach allows us 1) to compare plume tracer data to their 
source composition, 2) to establish the ${ }^{3} \mathrm{He}$ and thermal budget for a single vent site, and to put the results in perspective with respect to global hydrothermal fluxes.

\subsection{Comparison of the vent fluid results with other hydrothermal sites}

The ${ }^{3} \mathrm{He}$ end-member $(25 \pm 5 \mathrm{pmol} / \mathrm{kg})$ lies in the range of previously studied hydrothermal sites on mid-ocean ridges (Table 2). Unlike major and trace elements and reactive gases such as $\mathrm{CH}_{4}, \mathrm{H}_{2}, \mathrm{H}_{2} \mathrm{~S}$, whose concentrations in the hydrothermal fluids strongly depend on the geological nature of the substratum and local thermodynamical conditions, the mean ${ }^{3} \mathrm{He}$ end-member concentration averaged over the MAR and EPR sites where helium isotopes data are available (Table 2$)$ is relatively constant $(17.1 \mathrm{pmol} / \mathrm{kg}$, with a standard deviation of $5.4 \mathrm{pmol} / \mathrm{kg}$, or $32 \%$ in relative terms). This appears thus to reflect primarily the relative homogeneity of the upper mantle source with respect to helium geochemistry. This is all the more true for the ${ }^{3} \mathrm{He} /{ }^{4} \mathrm{He}$ ratio in hot fluids which varies in a very narrow range of $(8.0 \pm 0.5) \mathrm{R}_{\mathrm{a}}$ (relative standard deviation $\approx 6 \%$ ), in line with the range of most MORB ${ }^{3} \mathrm{He} /{ }^{4} \mathrm{He}$ data $\left(7-9 \mathrm{R}_{\mathrm{a}}\right)$.

${ }^{3} \mathrm{He} /$ heat ratios for mature hydrothermal vents - mean value $=(8.9 \pm 3.6) \times 10^{-18} \mathrm{~mol} / \mathrm{J}$ (Table 2) - exhibit a higher variability than that of the helium end-member, presumably in connection with variations in the water-rock ratio which translate into a variable rate of extraction of heat and ${ }^{3} \mathrm{He}$ from the hot basalt [16]. However, anomalously large short timescale variations of the ${ }^{3} \mathrm{He} /$ heat ratio at a single vent site have been observed, related to magmatic events on the Juan de Fuca Ridge [16-19] or directly associated with fresh lava flows (see for instance fig. 2 in ref. [19]). With a value of $(9.3 \pm 2) \times 10^{-18} \mathrm{~mol} / \mathrm{J}$, the Rainbow site exhibits a ${ }^{3} \mathrm{He} /$ heat ratio typical of that observed for mature sites, characterized by a well established steady-state circulation.

Large variations in the $\mathrm{CH}_{4} /{ }^{3} \mathrm{He}$ ratios are observed along mid-ocean ridges. Even for basaltic environments, the variability can be substantial : the $\mathrm{CH}_{4} /{ }^{3} \mathrm{He}$ ratio at EPR- $13^{\circ} \mathrm{N}$ and 
EPR $-21^{\circ} \mathrm{N}$ are $(1.7 \pm 0.4) \times 10^{6}[20]$ and $(5.0 \pm 1.5) \times 10^{6}$ [21] respectively while it is $65 \times 10^{6}$ at Lucky Strike and $85 \times 10^{6}$ at Menez Gwen on the MAR [11]. Mn/ ${ }^{3} \mathrm{He}$ ratios also display a large variability: for example, the $\mathrm{Mn} /{ }^{3} \mathrm{He}$ ratio of the $\mathrm{EPR}-13^{\circ} \mathrm{N}$ fluids is $13.7 \times 10^{6}$ [22] while it is more than $160 \times 10^{6}$ at the Galapagos Spreading Center [23]. Due to relative homogeneity of the ${ }^{3} \mathrm{He}$ end-member in mid-ocean ridge hydrothermal systems, the variations in the $\mathrm{CH}_{4} /{ }^{3} \mathrm{He}$ and $\mathrm{Mn} /{ }^{3} \mathrm{He}$ ratios essentially reflect the variations in the end-member value of these tracers. In the Rainbow fluids, $\mathrm{CH}_{4}$ concentrations are indeed among the highest for abiogenic methane [4] and reflect the production of methane by the serpentinization reactions in the ultramafic substratum. Manganese and other transition metals concentrations are also unusually high [3]. A comprehensive discussion of the geochemistry of these tracers in relation to the geological setting of the Rainbow site is available in [3] and [4].

\section{2. ${ }^{3}$ He and heat plume budgets}

Direct current observations, spanning the time when the plume samples were collected, were carried out with lowered ADCP. The results indicate that the local deep velocity field is strongly controlled by the topography [6] and show that the entire plume is advected across the Rainbow sill situated immediately NE of the vent site (see fig. 1 and fig. 3). LADCP measurements made in the saddle of the sill are in good agreement with those of the current meters moorings deployed during the cruise to monitor the water flow across the valley section on the sill and recovered in 1998 (i.e., after $\sim 400$ days of operation). This long-term monitoring shows that below $2000 \mathrm{~m}$, the direction and the intensity of the deep current advected over the sill are remarkably stable, corresponding to a mean water flux of $\Phi=(0.070 \pm 0.012) \times 10^{6} \mathrm{~m}^{3} / \mathrm{sec}[5]$. This cross-valley section on the Rainbow sill is an ideal location for calculating the ${ }^{3} \mathrm{He}$ flux advected with the plume. The best estimate of the mean $\delta^{3} \mathrm{He}$ integrated vertically across the sill between $2000 \mathrm{~m}$ and the sill depth is $\delta=(12.3 \pm 0.5) \%$ (fig. 6). Hence, the hydrothermal ${ }^{3} \mathrm{He}$ flux $\mathrm{Q}_{3 \mathrm{He}}$ transported across the sill 
is given by $\mathrm{Q}_{3 \mathrm{He}}=\Phi \times\left[{ }^{4} \mathrm{He}\right] \times \mathrm{R}_{\mathrm{a}} \times\left(\delta-\delta_{\mathrm{BG}}\right) / 100$, where $\left[{ }^{4} \mathrm{He}\right]$ is the helium concentration and $\delta_{\mathrm{BG}}$ is the $\delta^{3} \mathrm{He}$ background. With a mean measured helium concentration $\left[{ }^{4} \mathrm{He}\right]=1.75 \pm 0.1 \mu \mathrm{mol} / \mathrm{m}^{3}$ and $\delta_{\mathrm{BG}}=5 \%$, the ${ }^{3} \mathrm{He}$ flux transported by the plume is $\mathrm{Q}_{3 \mathrm{He}}=(12.3 \pm 3) \times 10^{-9} \mathrm{~mol} / \mathrm{sec}$. Knowing the end-member vent fluid ${ }^{3} \mathrm{He}$ concentration, we calculate that a flux of $490 \pm 220 \mathrm{~kg} / \mathrm{sec}$ of high-temperature fluid is required to sustain the ${ }^{3}$ He plume we observe.

The above ${ }^{3} \mathrm{He}$ flux can also be combined with the ${ }^{3} \mathrm{He} /$ heat ratio of the fluids to derive a thermal output of the Rainbow site of $1320 \pm 600 \mathrm{MW}$. This calculation assumes that ${ }^{3} \mathrm{He} /$ heat ratios in the focussed and diffuse vent fluids are identical. As a matter of fact, since both helium and heat are conservative tracers, they may locally occur in constant proportions. Thus we think that the above assumption is valid. This value is to compare with that for the Endeavour vent field on the Juan de Fuca Ridge, estimated around 1700 \pm 1100 MW based on advective transport of heat [24].

\subsection{Hydrothermal tracers dispersal}

Most plume tracer data were obtained within a distance of $\sim 20 \mathrm{~km}$ from the vent site. This portion of the plume, which corresponds roughly to the isoline $\delta^{3} \mathrm{He}=7.5 \%$, contains $0.021{ }^{3} \mathrm{He}$ moles in excess of the regional background (this figure was computed from the grid file used for the plot of figure 3 , with a plume shape between $2000 \mathrm{~m}$ and $2300 \mathrm{~m}$ depth approximated by triangles). Dividing this plume ${ }^{3} \mathrm{He}$ inventory by the ${ }^{3} \mathrm{He}$ flux transported by the dispersing plume, $\mathrm{Q}_{3 \mathrm{He}}=(12.3 \pm 3) \mathrm{nmol} / \mathrm{sec}$, leads to a bulk residence time of the plume in the rift valley of $\sim 20$ days. Over this period of time, the $\mathrm{CH}_{4} /{ }^{3} \mathrm{He}$ and $\mathrm{Mn} /{ }^{3} \mathrm{He}$ ratios calculated for the dispersing plume (fig. 4) and those measured in the vent fluids are identical, within the experimental uncertainties. These linear correlation among the tracers and the consistency of the ratios in the hot fluids and in the diluted plume show that, on this time 
scale, the different hydrothermal tracers behave conservatively with respect to one another in the plume and with respect to their source fluids. This is in agreement with available observations which show that the oxidation kinetics of $\mathrm{Mn}^{2+}$ and $\mathrm{CH}_{4}$ are such that they behave conservatively close to the vents [25-26].

\subsection{Comparison with global hydrothermal fluxes}

The spatial pattern of ${ }^{3} \mathrm{He}$ excess in the deep ocean strongly points to the prominent role played by the mid-ocean ridges with respect to ${ }^{3} \mathrm{He}$ mantle degassing, with major water column $\delta^{3} \mathrm{He}$ anomalies being centered above spreading centers in the East Pacific [27-28], in the Indian Ocean [29-30] and in the Atlantic [31]. To the first order, 3-D oceanic general circulation models make a good job at simulating the ${ }^{3} \mathrm{He}$ distribution with the simple assumption that the ${ }^{3} \mathrm{He}$ source intensity is linearly correlated to the spreading rate [32-33]. The slope of the correlation is $\sim 330{ }^{3} \mathrm{He} \mathrm{mol} / \mathrm{km}^{2}$ of crustal spreading, translating to a world average ${ }^{3} \mathrm{He}$ annual flux of $0.33 \mathrm{mmol}$ per kilometer of ridge and per millimeter/year of full spreading rate (fig. 7). The section of the MAR to which the Rainbow site belongs has a spreading rate close to $25 \mathrm{~mm} /$ year [34]. In order to plot the Rainbow site in the diagram displayed in fig. 7, one has to define the length of ridge involved. While Lucky Strike and Menez Gwen venting sites, situated further north, are in segment centres, the Rainbow site occurs within a non-transform discontinuity between the South AMAR and the AMAR segment. Therefore, it cannot directly be affected a single segment length. On the other hand, surveys of hydrothermal plumes on the MAR $36-38^{\circ} \mathrm{N}$ have yielded evidence for an average spacing between adjacent vent-sites of 25-30 km along-axis [35]. Assigning this length scale to the Rainbow site leads to a ${ }^{3} \mathrm{He}$ flux of $0.5 \pm 0.2 \mathrm{mmol}$ per kilometer of ridge per millimeter of spreading rate. This value is comparable to that for the Lucky Strike segment $(0.45 \mathrm{mmol} / \mathrm{km} / \mathrm{mm})$ [36]. Both sites are $\sim 40-50 \%$ above the world average $(0.33 \mathrm{mmol} / \mathrm{km} / \mathrm{mm})$, thus supporting earlier suggestion [35] that hydrothermal activity along 
this section of ridge axis close to the Azores Triple Junction is more intense than has been reported elsewhere on slow spreading ridges.

\section{Conclusion}

The main results of this helium isotopic study of the Rainbow hydrothermal site include the following:

1- The Rainbow site, although hosted in serpentinized diapir, i.e. a rather unusual geological environment compared to most already studied sites, displays a helium isotope geochemistry very similar to "classic" mid-ocean ridge sites.

2- From the compilation of mid-ocean ridge sites for which helium isotopes data are available, we come to the more general conclusion that, as far as helium geochemistry is concerned, the variability among hydrothermal sites is rather limited, with relative standard deviations of $34 \%$ and $6 \%$ for the ${ }^{3} \mathrm{He}$ end-member concentration and ${ }^{3} \mathrm{He} /{ }^{4} \mathrm{He}$ ratio respectively. This result points to the relative homogeneity of the helium isotope composition of upper mantle, also noted in MORB studies.

3- The ${ }^{3} \mathrm{He}$ budget leads to a plume residence time of $\sim 20$ days in the rift valley. On this time scale, ${ }^{3} \mathrm{He}$ correlates linearly with methane and manganese hydrothermal tracers throughout the dispersing plume. Furthermore, $\mathrm{CH}_{4} /{ }^{3} \mathrm{He}$ and $\mathrm{Mn} /{ }^{3} \mathrm{He}$ ratios are identical in the plume and in the hot fluids showing that the different hydrothermal tracers behave conservatively with respect to one another in the plume and with respect to their source fluids.

4- The ${ }^{3}$ He flux transported by the plume could be deduced from the measurement of the water transport across the sill which marks the entrance of the AMAR segment, allowing us to infer a thermal output of $1320 \mathrm{MW}$. Translated into a flux per km of ridge and per millimeter of spreading rate, this ${ }^{3} \mathrm{He}$ flux $(0.5 \mathrm{mmol} / \mathrm{km} / \mathrm{mm})$ is comparable to the flux calculated for the neighbouring Lucky Strike segment $(0.45 \mathrm{mmol} / \mathrm{km} / \mathrm{mm})$. Although the 
uncertainties are large, both fluxes are $\sim 40-50 \%$ above the world average $(0.33 \mathrm{mmol} / \mathrm{km} / \mathrm{mm})$, thus showing that the MAR south of the Azores discharges substantially more than its share of the global hydrothermal input to the ocean.

\section{Acknowledgements}

We would like to thank D. Pinti, M.D. Rudnicki, and one anonymous reviewer for their constructive comments on the manuscript. This research was undertaken as part of the Amores project supported by the European Commission (MAST program under contract MAS3-CT95-0040). 


\section{References}

[1] C.R. German, G.P. Klinkhammer and M.D. Rudnicki, The Rainbow hydrothermal plume, $36^{\circ} 15^{\prime}$ N, MAR, Geophys. Res. Lett. 23 (1996) 2979-2982.

[2] Y. Fouquet, F. Barriga, J.L. Charlou, H. Elderfield, C.R. German, H. Ondreas, L. Parson, J. Radford-Knoery, J. Relvas, A. Ribeiro, A. Schulz, R. Apprioual, P. Cambon, I. Costa, J.P. Donval, E. Douville, J.Y. Landuré, A. Normand, H. Pellé, E. Ponzevera, S. Riches, H. Santana, M. Stephan, FLORES diving cruise with the Nautile near the Azores - first dives on the rainbow field : hydrothermal seawater/mantle interaction. InterRidge News 7 (1998) 24-28.

[3] E. Douville, J.L. Charlou, E.H. Oelkers, P. Bienvenu, C.F. Jove Colon, J.P. Donval, Y. Fouquet, D. Prieur, P. Appriou, The Rainbow vents fluids $\left(36^{\circ} 14^{\prime} \mathrm{N}, \mathrm{MAR}\right)$ : the influence of ultramafic rocks and phase separation on trace metal content in Mid-Atlantic Ridge hydrothermal fluids, Chem. Geol. 184 (2002) 37-48.

[4] J.L. Charlou, J.P. Donval, Y. Fouquet, P. Jean-Baptiste and N. Holm, Geochemistry of high $\mathrm{H}_{2}$ and $\mathrm{CH}_{4}$ vent fluids issuing from ultramafic rocks at the Rainbow hydrothermal field (36² 14N, MAR), Chem. Geol. 191 (2002) 345-359.

[5] A.M. Thurnherr, K.J. Richards, C.R. German, G.F. Lane-Serff, K.G. Speer, Flow and mixing in the rift valley of the Mid-Atlantic Ridge, J. Phys. Oceanography, 32 (2002) 1763-1778.

[6] C.R. German, K.J. Richards, M.D. Rudnicki, M.M. Lam, J.L. Charlou and the FLAME Scientific Party, Topographic control of a dispersing hydrothermal plume, Earth Planet. Sci. Lett. 156 (1998) 267-273.

[7] H. Bougault, M. Aballea, J.Radford-Knoery, J.L.Charlou, P.Jean-Baptiste, P.Appriou, D.Needham, C. German and M. Miranda, FAMOUS and AMAR segments on the MidAtlantic Ridge : ubiquitous hydrothermal $\mathrm{Mn}, \mathrm{CH}_{4}, \delta^{3} \mathrm{He}$ signals along the rift valley walls and offsets, Earth Planet. Sci. Lett. (1998) 161, 1-17.

[8] P. Jean-Baptiste, F.Mantisi, A.Dapoigny, M.Stievenard. Design and performance of a mass spectrometric facility for measuring helium isotopes in natural waters and for lowlevel tritium determination by the ${ }^{3} \mathrm{He}$ ingrowth method, Appl. Radiat. Isot. 43 (1992) 881-891.

[9] P. Jean-Baptiste, J. L. Charlou, M. Stievenard, J. P. Donval, H. Bougault, and C. Mével, Helium and methane measurements in hydrothermal fluids from the Mid-Atlantic Ridge: the Snake Pit at $23^{\circ}$ N, Earth Planet. Sci. Lett., 106 (1991) 17-28. 
[10] J.L. Charlou, Y.Fouquet, J.P. Donval, J.M. Auzende, P. Jean-Baptiste, M. Stievenard, S. Michel, Mineral and gas chemistry of hydrothermal fluids on an ultrafast spreading ridge: East Pacific Rise, $17^{\circ} \mathrm{S}$ to $19^{\circ} \mathrm{S}$ (Naudur cruise) - phase separation processes controlled by volcanic and tectonic activity, J. Geophys. Res. 101 (1996) 15899-15919.

[11] J.L. Charlou, J.P. Donval, E. Douville, P. Jean-Baptiste, J. Radford-Knoery, Y. Fouquet, A. Dapoigny and M. Stievenard, Compared geochemical signatures and evolution of Menez Gwen $\left(37^{\circ} 50 \mathrm{~N}\right)$ and Lucky Strike $\left(37^{\circ} 17 \mathrm{~N}\right)$ hydrothermal fluids, south of the Azores Triple junction on the Mid-Atlantic Ridge, Chem. Geol. 171 (2000) 49-75.

[12] J.L. Charlou, J.P. Donval, T. Zitter, N. Roy, P. Jean-Baptiste, J.P. Foucher, J. Woodside, MEDINAUT Scientific Party, Evidence of methane venting and geochemistry of brines on mud volcanoes of the eastern Mediterranean Sea, Deep Sea Res.I, 50 (2003) 941-958.

[13] W. Jenkins, Tritium and helium-3 results: TTO-NAS and NATS 1981, data release\#3, WHOI Helium Isotopes Laboratory (1989).

[14] C. Andrié, P. Jean-Baptiste and L. Merlivat, Tritium and helium-3 in the northeastern Atlantic ocean during the 1983 Topogulf cruise, J. Geophys. Res. 93 (1988) 12511-12524.

[15] M.D. Rudnicki, R.H. James, H. Elderfield, Near-field variability of the TAG nonbuoyant plume, 26N Mid-Atlantic Ridge, Earth Planet. Sci. Lett. 127 (1994) 1-10.

[16] J.E. Lupton, E.T. Baker and G.J. Massoth, Variable ${ }^{3} \mathrm{He} /$ heat ratios in submarine hydrothermal systems: evidence from two plumes over the Juan de Fuca ridge, Nature 337 (1989) 161-164.

[17] E.T. Baker, J.W. Lavelle, R.A. Feely, G.J. Massoth and S.L. Walker, Episodic venting of hydrothermal fluids from the Juan de Fuca Ridge, J. Geophys. Res. 94(B7) (1989) 92379250.

[18] J.E. Lupton, E.T. Baker and G.J. Massoth, R.E. Thomson, B.J. Burd, D.A. Butterfield, R.W. Embley and G.A. Cannon, Variations in water column ${ }^{3} \mathrm{He} /$ heat ratios associated with the CoAxial event, Juan de Fuca Ridge, Geophys. Res. Letters 22 (1995) 155-158.

[19] J.E. Lupton, E.T. Baker and G.J. Massoth, Helium, heat, and the generation of hydrothermal event plumes at mid-ocean ridges, Earth Planet. Sci. Lett. 171 (1999) 343350 . 
[20] L. Merlivat, F. Pineau and M. Javoy, Hydrothermal vent waters at $13^{\circ} \mathrm{N}$ on the East Pacific Rise : isotopic composition and gas concentration, Earth Planet. Sci. Lett. (1987) 100-108.

[21] J.A. Welhan and H. Craig. Methane, hydrogen and helium in hydrothermal fluids at $21^{\circ} \mathrm{N}$ on the East Pacific rise, in : P. Rona (Ed.), Hydrothermal Processes at Seafloor spreading centers, Proceedings of NATO Advanced Research Institute, Plenum Press, New York, 1983, pp.391-409.

[22] J.L. Charlou, H. Bougault, P. Appriou, P. Jean-Baptiste, J. Etoubleau, A. Birolleau, Water column anomalies associated with hydrothermal activity between $11^{\circ} 40$ and $13^{\circ} \mathrm{N}$ on the East Pacific Rise: Discrepancies between tracers, Deep Sea Res. 38 (1991) 569596.

[23] R.F. Weiss, Hydrothermal manganese in the deep-sea : scavenging residence time and $\mathrm{Mn} /{ }^{3}$ He relationships, Earth Planet. Sci. Lett. 37 (1977) 257-262.

[24] E.T. Baker and G.J.Massoth, Characteristics of hydrothermal plumes from two vent fields on the Juan de Fuca Ridge, northeast Pacific Ocean, Earth Planet. Sci. Lett. 85 (1987) 59-73.

[25] J.P. Cowen, G.J. Massoth and R.A. Feely, Scavenging rates of dissolved manganese in a hydrothermal vent plume, Deep-Sea Res. 37 (1990) 1619-1637.

[26] D. Kadko, N.D. Rosenberg, J.E. Lupton, R.W. Collier, M.D. Lilley, Chemical reaction rates and entrainment within the Endeavour Ridge hydrothermal plume, Earth Planet. Sci. Lett. 99 (1990) 315-335.

[27] J.E. Lupton and H. Craig, A major helium-3 source at $15^{\circ} \mathrm{S}$ on the East Pacific Rise, Science 214 (1981) 13-18.

[28] R. Well, J. Lupton, W. Roether, Crustal helium in deep Pacific waters, J. Geophys. Res. 106(C7) (2001) 14165-14177.

[29] P. Jean-Baptiste, F. Mantisi, H. Pauwells, D. Grimaud and P. Patriat, Hydrothermal helium-3 and manganese plumes at $19^{\circ} 29$ South on the Central Indian Ridge, Geophys. Res. Lett. 19 (1992) 1787-1790.

[30] D. Jamous, L. Memery, C. Andrié, P. Jean-Baptiste, L. Merlivat, The distribution of helium-3 in the deep Western and Southern Indian ocean, J. Geophys. Res. 97(C2) (1992) $2243-2250$.

[31] C.Rueth, R. Well, W. Roether, Primordial He-3 in South Atlantic deep waters from sources on the Mid-Atlantic Ridge, Deep-Sea Res. I 147 (2000) 1059-1075. 
[32] K.A. Farley, E. Maier-Reimer, P. Schlosser, W.S. Broecker, Constraints on mantle ${ }^{3} \mathrm{He}$ fluxes and deep-sea circulation from an oceanic general circulation model, J. Geophys. Res. 100(B3) (1995) 3829-3839.

[33] J.C. Dutay, P. Jean-Baptiste, J.M. Campin, A. Ishida, E. Maier-Reimer, R.J. Matear, A. Mouchet, I.J. Totterdell, Y. Yamanaka, K. Rodgers, G. Madec, J.C. Orr, Evaluating OCMIP-2 ocean models'deep circulation using the natural ${ }^{3} \mathrm{He}$ tracer field, J. Marine Systems (in press).

[34] H. Sloan and P. Patriat, Kinematics of the North American-African plate boundary between $28^{\circ}$ and $29^{\circ} \mathrm{N}$ during $10 \mathrm{Ma}$ : evolution of the axial geometry and spreading rate and direction, Earth Planet. Sci. Lett. 113 (1992) 323-341.

[35] C.R. German, L.M. Parson, HEAT Scientific Team, Hydrothermal exploration near the Azores Triple Junction : tectonic control of venting at slow-spreading ridges ?, Earth Planet. Sci. Lett. 138 (1996) 93-104.

[36] P. Jean-Baptiste, H. Bougault, A. Vangriesheim, J.L. Charlou, J.Radford-Knoery, Y.Fouquet, D.Needham and C. German, Mantle ${ }^{3} \mathrm{He}$ in hydrothermal vents and plume of the Lucky Strike site (MAR 37 $17 \mathrm{~N}$ ) and associated geothermal heat flux, Earth Planet. Sci. Lett. 157 (1998) 69-77.

[37] P. Jean-Baptiste (unpublished data).

[38] M.D. Rudnicki and H. Elderfield, Helium, radon and manganese at the TAG and Snakepit hydrothermal vent fields, $26^{\circ}$ and $23^{\circ} \mathrm{N}$, Mid-Atlantic Ridge, Earth Planet. Sci. Lett. 113 (1992) 307-321.

[39] J.L. Charlou, J.P. Donval, P. Jean-Baptiste, P. Rona and A. Dapoigny, Gases and helium isotopes in high temperature solutions sampled before and after ODP leg 158 drilling at TAG hydrothermal field (26 N, MAR), Geophys. Res. Lett. 23 (1996) 3491-3494.

[40] W.J. Jenkins, J.M. Edmonds, J.B. Corliss, Excess ${ }^{3} \mathrm{He}$ and ${ }^{4} \mathrm{He}$ in Galapagos submarine hydrothermal waters, Nature 272 (1978) 156-158.

[41] L. Merlivat, C. Andrié, P. Jean-Baptiste, Distribution des isotopes de l'hydrogène, de l'oxygène et de l'hélium dans les sources hydrothermales sous-marines de la ride EstPacifique à $13^{\circ}$ N, C.R. Acad. Sc. Paris 299 (1984) 1191-1196.

[42] K.R. Kim, J.A. Welhan and H. Craig, The hydrothermal vent fields at $13^{\circ} \mathrm{N}$ and $11^{\circ} \mathrm{N}$ on the East Pacific Rise : Alvin 1984 results, EOS 65 (1984) 973. 
[43] P. Jean-Baptiste, J.L. Charlou, Y. Fouquet, A. Dapoigny, M. Stievenard, J.P. Donval and J.M. Auzende, Helium and oxygen isotope analyses of hydrothermal fluids from the East Pacific Rise between $17^{\circ} \mathrm{S}$ and $19^{\circ} \mathrm{S}$, Geo-Marine Letters 17 (1997) 213-219.

[44] P. Jean-Baptiste, E. Fourré, N. Metzl, J.F. Ternon, A. Poisson, Red Sea Deep Waters circulation and ventilation rate deduced from the ${ }^{3} \mathrm{He}$ and ${ }^{14} \mathrm{C}$ tracer fields, J. Marine Systems (in press).

[45] H. Craig, W.B. Clarke, M.A. Beg, Excess ${ }^{3}$ He in deep water on the East Pacific Rise, Earth Planet. Sci. Lett. 26 (1975) 125-132. 


\section{Table captions}

Table 1: Rainbow vents fluids helium isotopes data (the uncertainty in the ${ }^{3} \mathrm{He} /{ }^{4} \mathrm{He}$ ratio is within $\pm 0.05 R_{a}$, with a relative error in the helium concentration $<5 \%$ ).

Table 2: Compilation of helium isotopes and heat data for hydrothermal vents from the MidAtlantic Ridge and East Pacific Rise.

\section{Figure captions}

Fig. 1: Bathymetric 3-D map of the Rainbow area.

Fig. 2: Selected $\delta^{3} \mathrm{He}$ vertical profiles along the dispersing plume (solid lines). The location of the stations (a to d) is shown in figure $3 . \delta^{3} \mathrm{He}$ vertical profiles at nearby stations outside the central rift (dashed lines) are also displayed to define the regional helium-3 background : NATS (1981) stations $n^{\circ} 60\left(36^{\circ} 25 \mathrm{~N} / 34^{\circ} 38 \mathrm{~W}\right), \mathrm{n}^{\circ} 61\left(36^{\circ} 25 \mathrm{~N} / 33^{\circ} 67 \mathrm{~W}\right)$, $\mathrm{n}^{\circ} 65\left(36^{\circ} 25 \mathrm{~N} / 30^{\circ} 25 \mathrm{~W}\right)$ and $\mathrm{n}^{\circ} 66\left(36^{\circ} 25 \mathrm{~N} / 29^{\circ} 27 \mathrm{~W}\right)$ [13], and TOPOGULF (1983) station $\mathrm{n}^{\circ} 83\left(40^{\circ} 00 \mathrm{~N} / 35^{\circ} 00 \mathrm{~W}\right)[14]$. (N.B. the $\delta^{3} \mathrm{He}$ maximum in the upper 1000 meters reflects the transient signal produced by the radioactive decay of bomb tritium).

Fig. 3 : Horizontal distribution of the $\delta^{3} \mathrm{He}(\%)$ maximum associated with the Rainbow hydrothermal plume in the 2000-2300 m range (coordinates in decimal degree). Letters a to d indicate the location of the stations displayed in figure 2. The dashed line shows the position of the Rainbow sill, NE of the vent site. Darkly shaded regions are less than $2000 \mathrm{~m}$.

Fig. 4 : Manganese (a) and methane (b) as a function of ${ }^{3} \mathrm{He}$ in the hydrothermal plume. Fig. $5:{ }^{3} \mathrm{He}-{ }^{4} \mathrm{He}$ relationship (a) and helium $\left({ }^{4} \mathrm{He}\right)$ concentration versus magnesium (b) in the vent fluids.

Fig. $6: \delta^{3} \mathrm{He}(\%)$ vertical section across the sill located NE of the vent site. Due to the lack of stations at the exact location of the sill, the section was reconstructed from the horizontal grid file used for plotting figure 3 (on the vertical, the shape of the profile in the range 2000$2300 \mathrm{~m}$ was approximated by a triangle).

Fig. $7:{ }^{3} \mathrm{He}$ annual flux per kilometer of ridge as a function of spreading rate. The dashed line is the linear relationship used in GCM simulations [32-33]. Lucky Strike and Red Sea values 
are calculated from reference [36] and [44]. The global average corresponds to the classic value of $4 \pm 1{ }^{3} \mathrm{He}$ atom $/ \mathrm{cm}^{2} / \mathrm{sec}$ estimated by Harmon Craig and his colleagues thirty years ago [45]. 


\begin{tabular}{|c|c|c|c|c|c|}
\hline $\begin{array}{c}\text { Vent } \\
\text { marker }\end{array}$ & Sample & $\begin{array}{c}\text { Temperature } \\
\left({ }^{\circ} \mathrm{C}\right)\end{array}$ & $\mathrm{R} / \mathrm{Ra}$ & $\begin{array}{c}{\left[{ }^{4} \mathrm{He}\right]} \\
(\mu \mathrm{mol} / \mathrm{kg})\end{array}$ & $\begin{array}{c}\mathrm{Mg} \\
(\mathrm{mmol} / \mathrm{kg})\end{array}$ \\
\hline 2 & PL03-G2 & - & 6.80 & 0.22 & 45.5 \\
\hline 3 & PL04-D3 & 351 & 7.75 & 1.00 & 29.6 \\
\hline 3 & PL07-G2 & 351 & 7.18 & 2.04 & 11.2 \\
\hline 4 & PL03-D3 & 354 & 7.02 & 0.70 & 33.3 \\
\hline 4 & PL03-G3 & 354 & 5.71 & 0.23 & 48.3 \\
\hline 4 & PL05-EG & 354 & 7.34 & 1.93 & 9.5 \\
\hline 5 & PL04-G2 & 362 & 6.73 & 0.12 & 46.1 \\
\hline 5 & PL09-D2 & 362 & 7.66 & 2.49 & 3.3 \\
\hline 7 & PL06-D2 & - & 7.61 & 1.55 & 3.7 \\
\hline 9 & PL10-D2 & 364 & 7.56 & 2.89 & 2.1 \\
\hline SW & deep water & $3-4$ & 1.05 & 0.0017 & 52.9 \\
\hline
\end{tabular}

Table 1 


\begin{tabular}{|c|c|c|c|c|}
\hline Hydrothermal sites & $\begin{array}{l}{ }^{3} \mathrm{He} \text { conc. } \\
(\mathrm{pmol} / \mathrm{kg})\end{array}$ & $\mathrm{R} / \mathrm{R}_{\mathrm{a}}$ & $\begin{array}{c}{ }^{3} \mathrm{He} / \text { Heat } \\
\left(10^{-18} \mathrm{~mol} / \mathrm{J}\right)\end{array}$ & Reference \\
\hline MAR & & & & \\
\hline$\overline{\text { Logatchev }\left(14.45^{\circ} \mathrm{N}\right)}$ & - & 7.2 & - & {$[37]$} \\
\hline Snake Pit $\left(23^{\circ} \mathrm{N}\right)$ & $23.8 \pm 1.6$ & 8.4 & $12.4 \pm 1.2$ & [9] \\
\hline Snake Pit $\left(23^{\circ} \mathrm{N}\right)$ & $12.5 \pm 1.5$ & 7.9 & $6.5 \pm 0.8$ & {$[38]$} \\
\hline TAG $\left(26^{\circ} \mathrm{N}\right)$ & $20.1 \pm 2.2$ & 7.5 & $9.3 \pm 1.1$ & {$[38]$} \\
\hline TAG $\left(26^{\circ} \mathrm{N}\right)$ & $16.7 \pm 1.4$ & 8.2 & $7.7 \pm 0.8$ & [39] \\
\hline Broken Spur $\left(29^{\circ} \mathrm{N}\right)$ & - & 8.9 & - & {$[37]$} \\
\hline Rainbow $\left(36^{\circ} 14 \mathrm{~N}\right)$ & $25.0 \pm 5$ & 7.51 & $9.3 \pm 2$ & this work \\
\hline Lucky Strike $\left(37^{\circ} 17 \mathrm{~N}\right)$ & $10 \pm 3.5$ & 8.13 & $6.5 \pm 1.2$ & {$[36]$} \\
\hline Menez Gwen $\left(37^{\circ} 50 \mathrm{~N}\right)$ & $20 \pm 4$ & 8.65 & $17.8 \pm 3.5$ & {$[11]$} \\
\hline EPR & & & & \\
\hline$\overline{\text { Galapagos }}$ & - & 7.8 & $5.2 \pm 0.4$ & {$[40]$} \\
\hline $\mathrm{EPR} 21^{\circ} \mathrm{N}$ & $12.4 \pm 2.3$ & 7.8 & $5.2 \pm 0.9$ & {$[21]$} \\
\hline $\mathrm{EPR} 13^{\circ} \mathrm{N}$ & $21 \pm 7$ & 7.6 & $11.0 \pm 3.7$ & [41] \\
\hline $\mathrm{EPR} 11^{\circ} \mathrm{N}$ & $17.9 \pm 8$ & 8.32 & $9.5 \pm 4$ & {$[42]$} \\
\hline $\mathrm{EPR} 18^{\circ} \mathrm{S}$ & $9.2 \pm 3$ & 8.3 & $6.2 \pm 2$ & {$[43]$} \\
\hline$\frac{\text { Global average for mature sites }}{\text { standard deviation }(\sigma)}$ & $\begin{array}{l}\mathbf{1 7 . 1} \\
(5.4)\end{array}$ & $\begin{array}{l}\mathbf{8 . 0} \\
(0.5)\end{array}$ & $\begin{array}{c}8.9 \\
(3.6)\end{array}$ & \\
\hline $\begin{array}{l}\text { Juan de Fuca : } \\
\text { - event Plume } \\
\text { - associated deep plume } \\
\text { - over fresh lava flows }\end{array}$ & $\begin{array}{l}- \\
-\end{array}$ & $\begin{array}{l}7.9 \\
7.9\end{array}$ & $\begin{array}{l}3.2-4.3 \\
14-47 \\
22-75\end{array}$ & $\begin{array}{l}{[19]} \\
{[19]} \\
{[19]}\end{array}$ \\
\hline
\end{tabular}

Table 2 


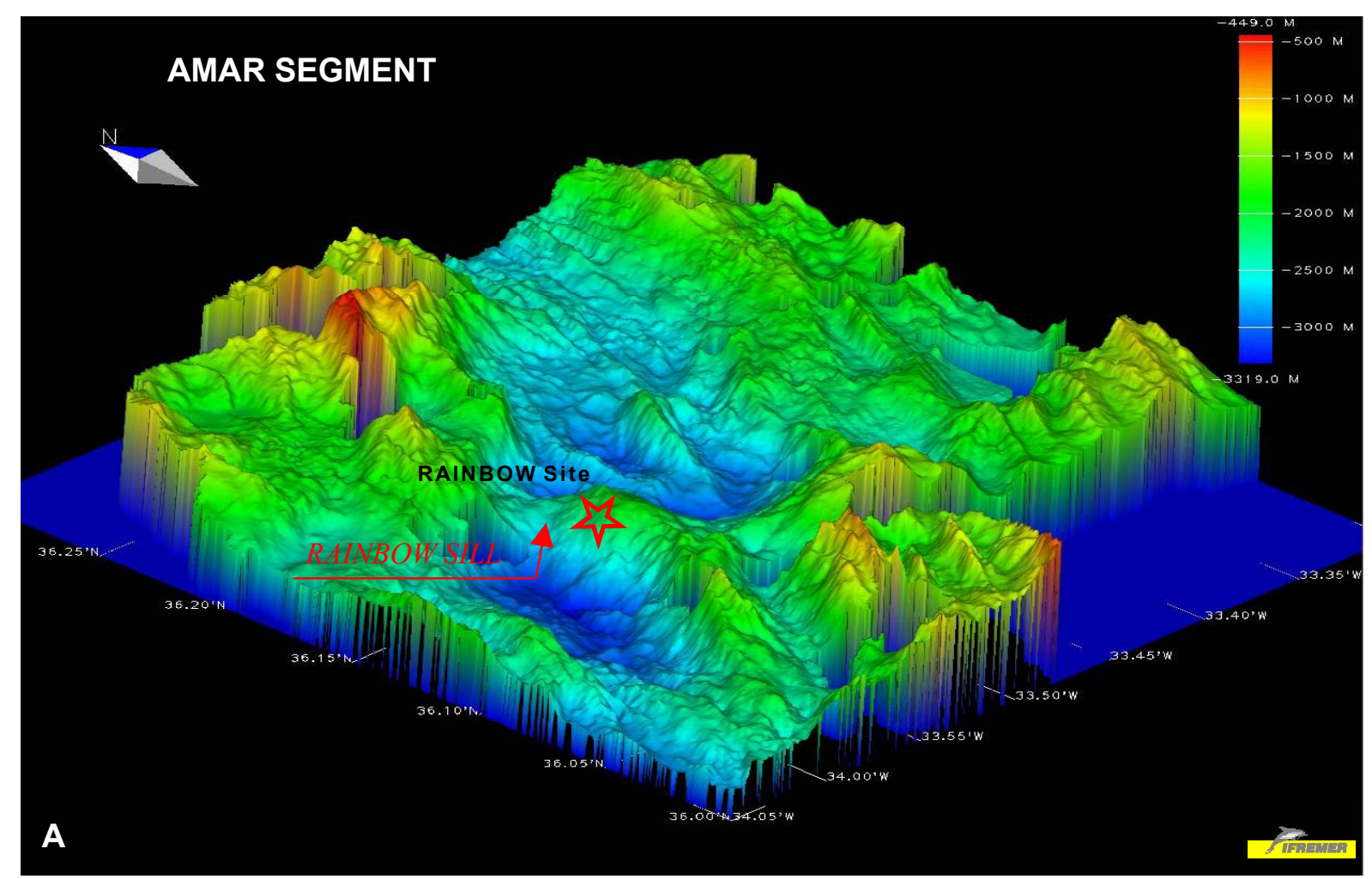




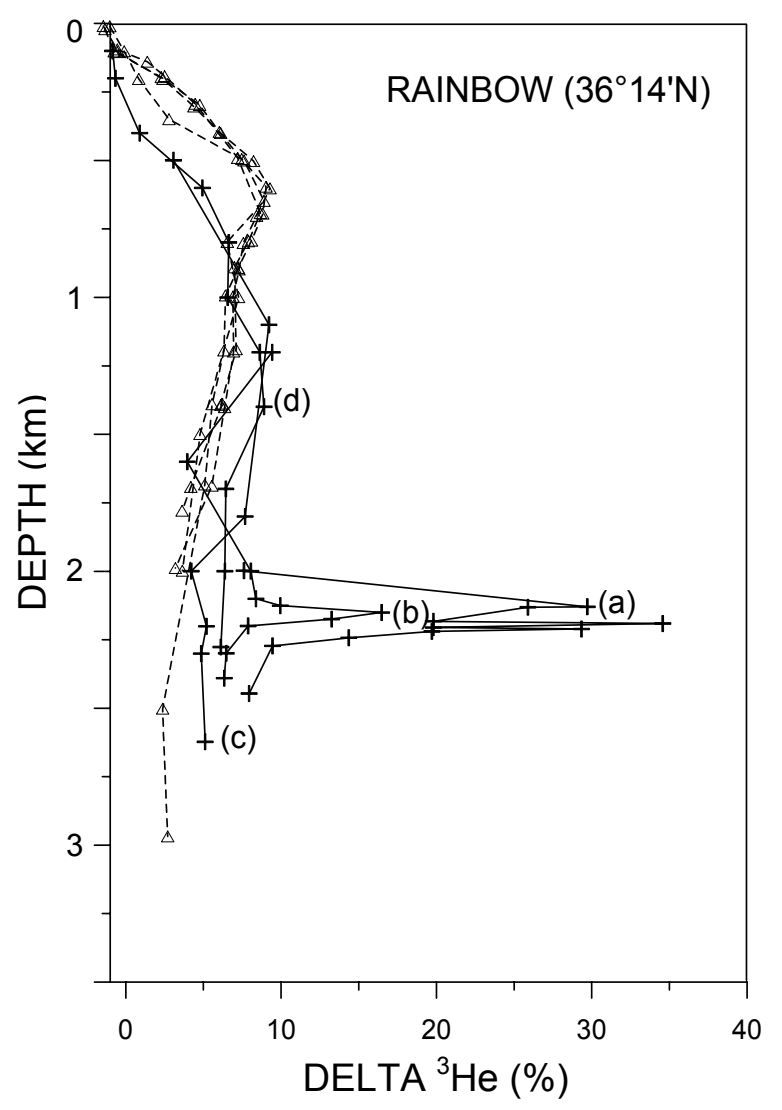

Figure 2 


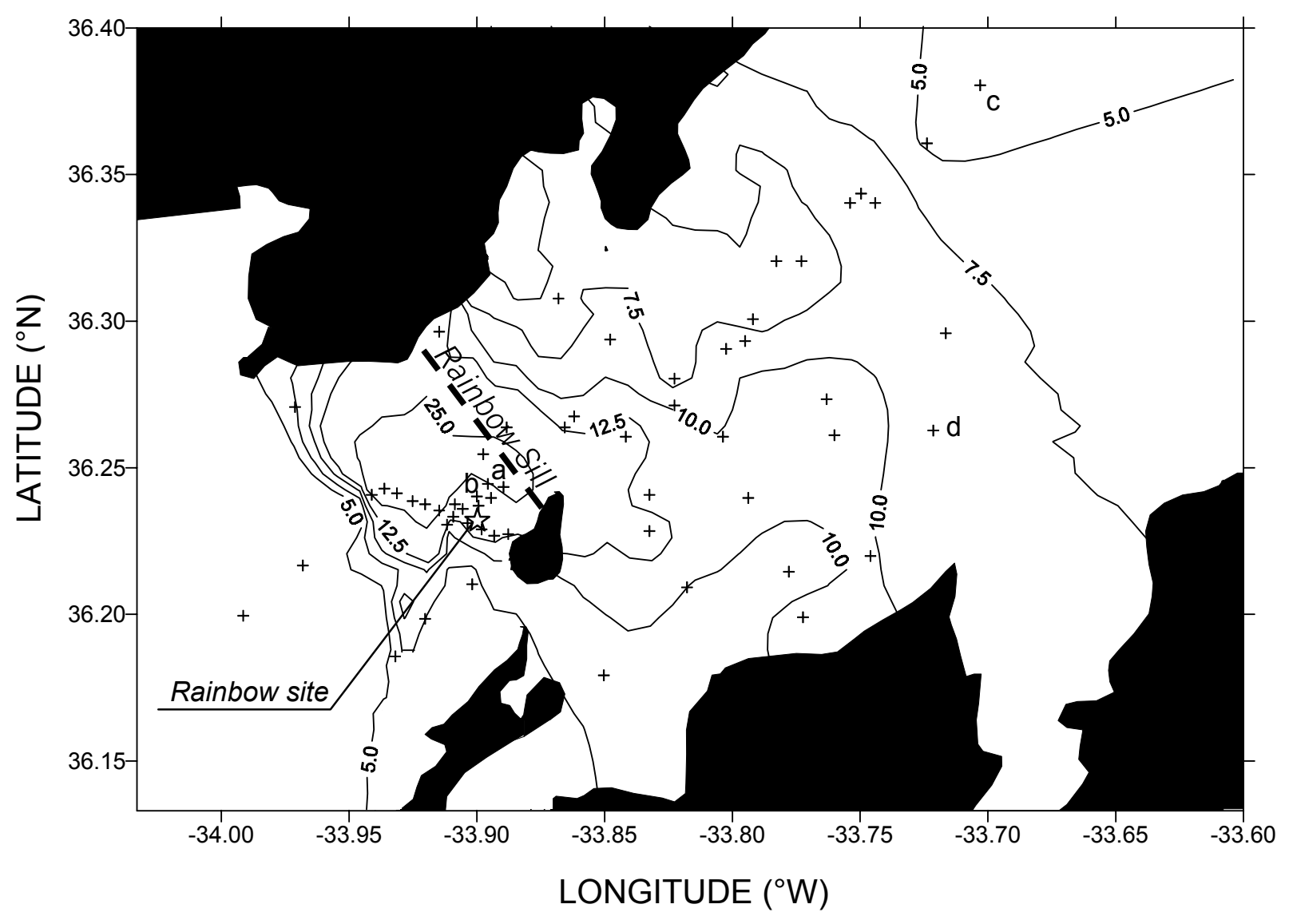

Figure 3 

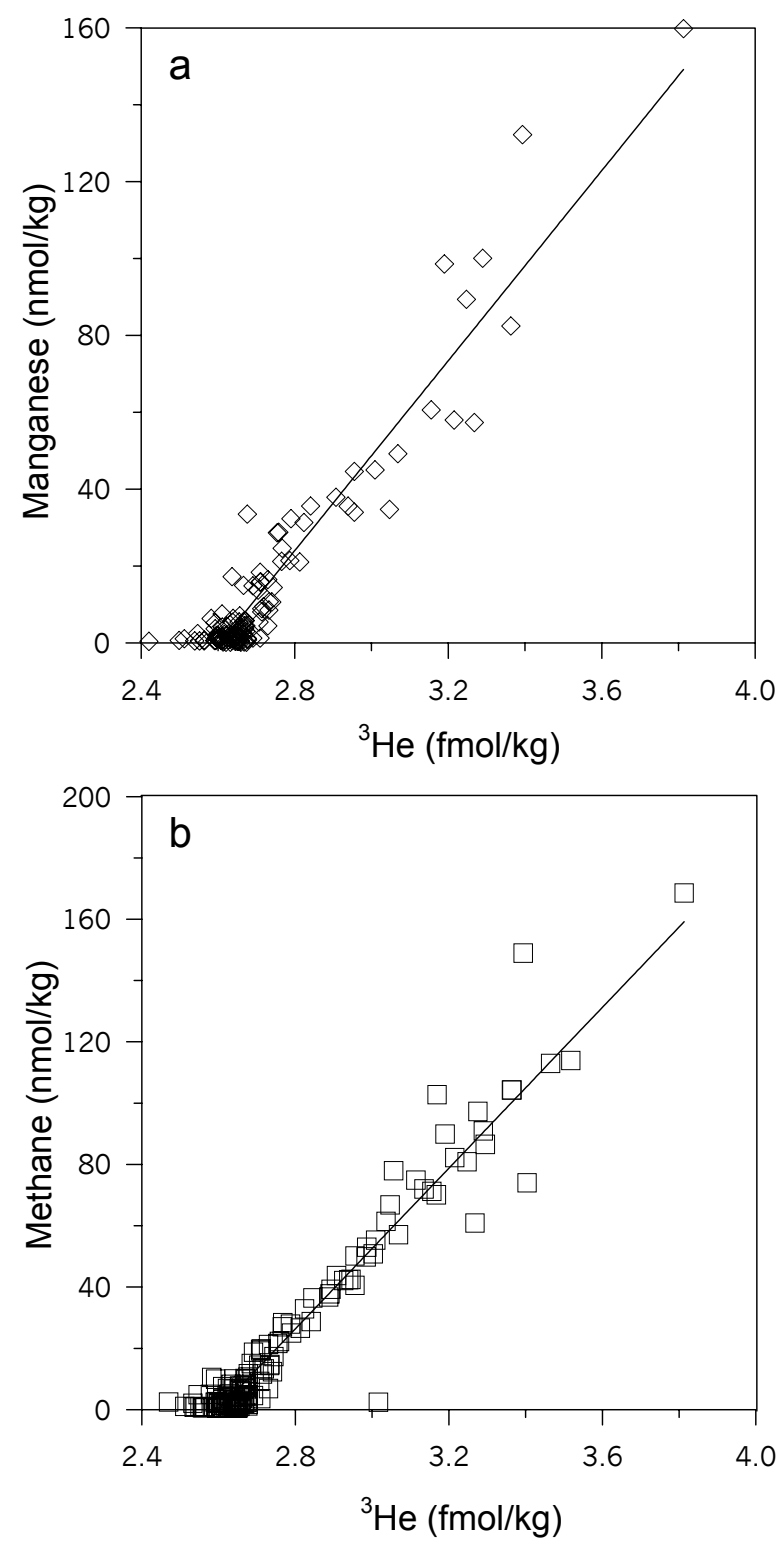

Figure 4 

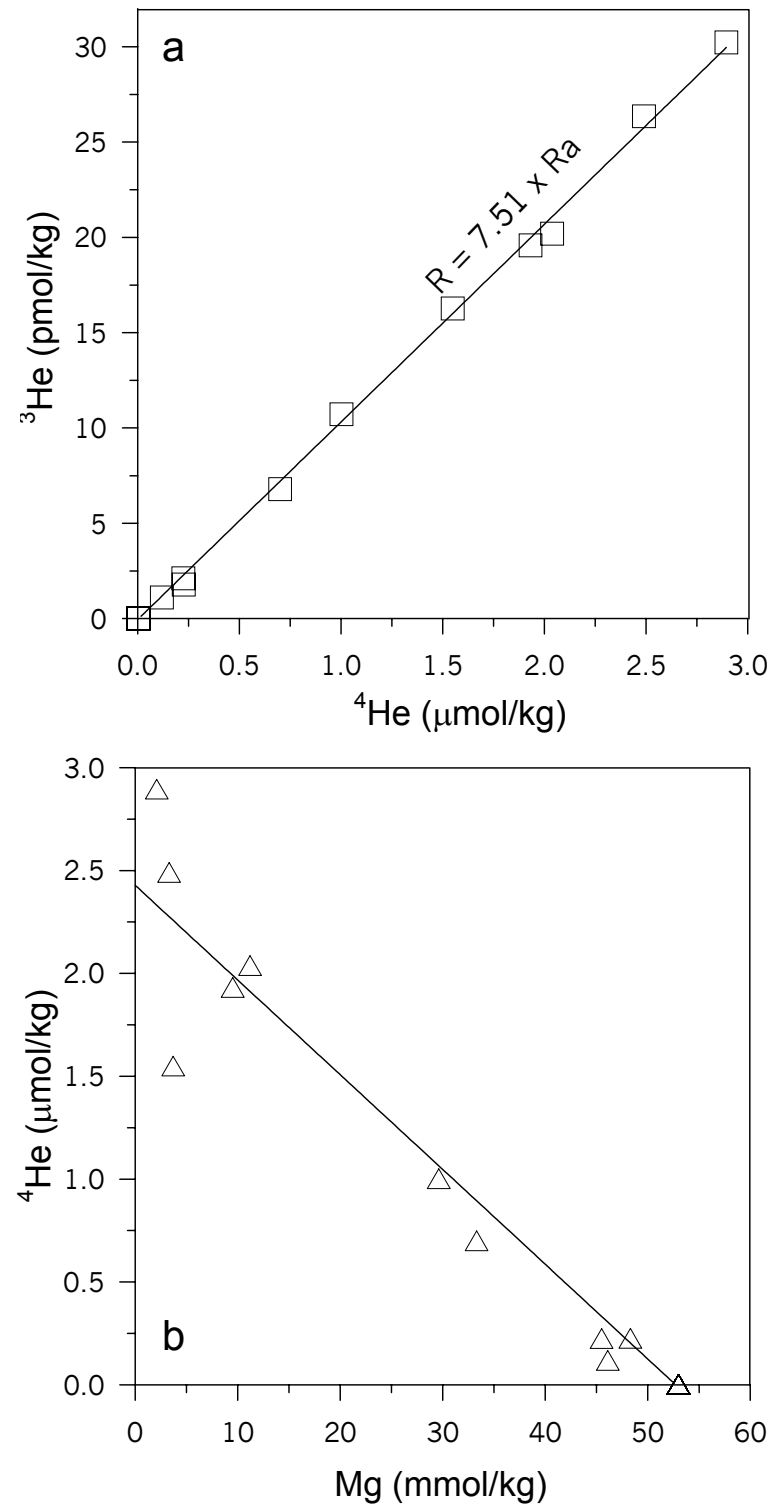

Figure 5 


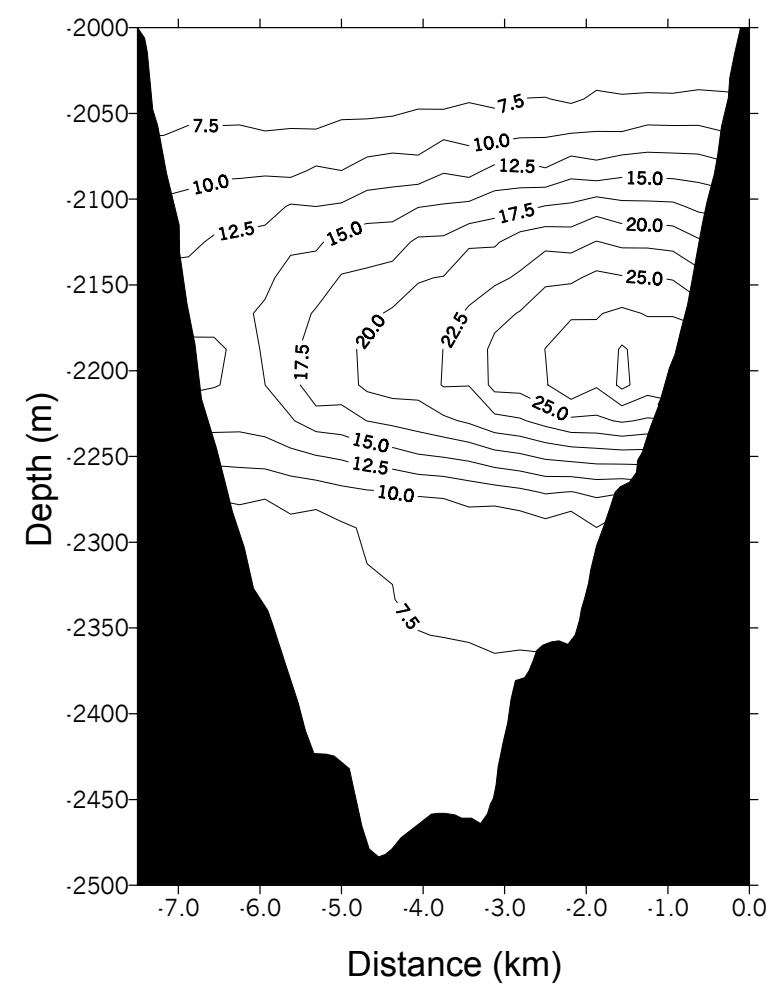

Figure 6 


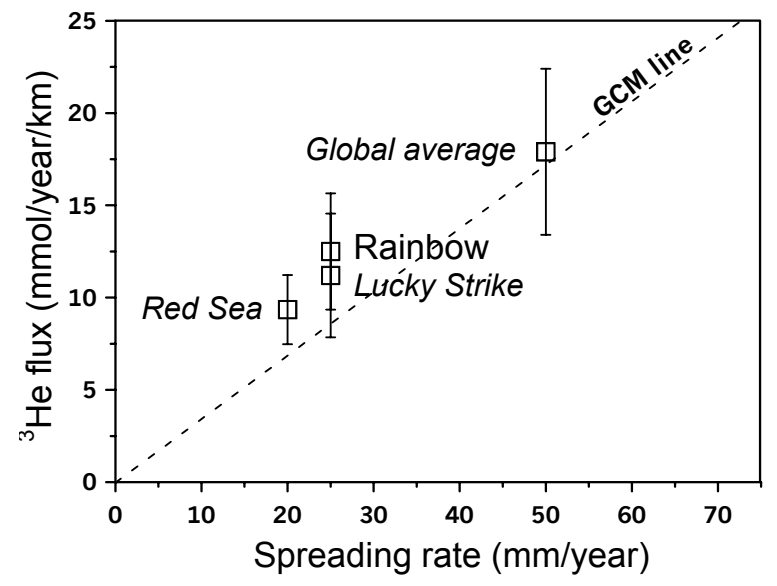

Figure 7 